\title{
Volatility Spillover USD-IDR Exchange Rate With Indonesia Stock Price
}

\author{
Naupal Irfan Firdaus \\ naupalirpanfirdaus@gmail.com \\ Andrieta Shintia Dewi \\ Aldilla Iradianty \\ Faculty of Economic and Business, Telkom University
}

\begin{abstract}
Value of imports higher than exports, causing the trade deficit, the appreciation of the currency in the developed countries, and withdrawals by foreign investors on the Indonesian stock exchange market. These things cause the movement of the exchange rate USD-IDR and Indonesian Stock Price are volatile and tend to weaken in the period from January 3, 2011 - August 31, 2016. This study to determine spillover volatility of the exchange rate USD-IDR with Indonesian Stock Price. By using current time series data, analyzed by Augmented Dickey-Fuller (ADF), GARCH, and Granger Causality. The results of the data processing rate of USD-IDR and data Indonesian Stock Price stationary at first difference by changing the level of daily data into a return of the respective data. Data having problems heteroskedasticity so it can be analyzed using GARCH. Results of the analysis showed that there is a volatility spillover between the two data. Then granger causality test results show that the causality occurs in both directions, meaning that changes in the foreign exchange market to give effect to the capital markets, and vice versa.
\end{abstract}

Keywords: spillover volatility, GARCH, foreign exchange market, capital market, exchange rate USD-IDR, indonesian stock price.

\section{INTRODUCTION}

The foreign exchange market has a term called the exchange rate, which was happened when the demand and supply on the foreign exchange. Exchange rate is the value of a country's currency value or the price level when the redeemable value of a currency of another country (Keown et.al. 2010). Exchange rate that occurred in Indonesia is the rate that shows the value of the rupiah (IDR) in term of foreign currency. Where the value of the rupiah (IDR) to the value of the US dollar (USD) experienced fluctuating changes every time. Any change of the exchange rate is entered to record foreign currency exchange market. Exchange rate that occurred in Indonesia is the rate that shows the value of the rupiah (IDR) in term of foreign currency. Where the value of the rupiah (IDR) to the value of the US dollar (USD) often experience fluctuating every time. Every movement of the exchange rate is entered to record exchange Foreign Exchange Market.

Not only the Foreign Exchange market just experiencing the flow of each day, the Capital Market has also experienced the same thing. Capital Markets is a market for long-term share of financial instruments that can be traded either debt securities (bonds), equities (stocks), mutual funds, and derivative financial instruments. Indonesia itself has a stock market that is known by the Indonesian Stock Exchange (BEI). The movement of the stock exchanges in Indonesia can be seen from Indonesian Stock Price rate on record that publish every day.

The movement of both markets were quite volatile due to several factors, one of which is the level of exports and imports. Indonesia's exports on July 2013 increased $2.4 \%$ from the previous month, but the value of Indonesia's imports also increased significantly compared with the same period a year earlier. The value of imports in July 2013 increased by $11.4 \%$ increased by $6.5 \%$ from the previous year in the same period on July 2012. The increase in the value of imports is greater than the value of exports had sparked trade deficit that will be even greater. (User. 2013) In 2013 the exchange rate of the rupiah (IDR) has depreciated of the currency against the US dollar (USD) which is 
the currency of the International. (Bappenas Document)

In addition, the strengthening of the American currency as the currency of the International, making foreign investors in Indonesia capital market pull back their shares to back the currency of the country of origin. Share ownership by foreign investors with $64.5 \%$ greater number of shares ownership of local investors, it is because local investors prefer corporate bonds and sukuk in investing, with proprietary data of $92.7 \%$. (KSEI Annual Report, 2015) Therefore, the movements that occurred in foreign exchange markets and capital markets experienced a volatile weakening.

In the early period this research dated on January 3 , 2011 exchange rate of USD-IDR stood at Rp.8.967.00 per 1 USD. The value of experiencing significant volatility, on February 23, 2012 the exchange rate remained at a value of Rp.9.059.00 per 1 USD. And continue to have movements which on 29 September 2015 the exchange rate touched a Rp.14.728.00 per 1 USD.

Experienced weakening exchange rate USD-IDR, also experienced by the capital markets products is stock, it is because investor expectations for the economy of a country, which is where the views of the exchange rate which is likely describe the circumstances of the economy of a country. In the period of the study itself, the rate of movement of the stock market recorded a considerable degree of fluctuation is equal to the rate of movement of the exchange rate USD-IDR. Where at the beginning of the study period, the value of Indonesian Stock Price is at a value Rp.3.727,52 and fluctuate up and down. At the end of the period the value of Indonesian Stock Price is higher than the value at beginning of period on the value of Rp.5372.10. But the journey as well as the value of Indonesian Stock Price USD-IDR exchange rate fluctuated with the level experienced high volatility.

The rate of change of which tend to be similar both allows the relationship between the two conditions of the market, the possibility of foreign exchange market (exchange rate) impact of contagion effects (spillover) to the capital market (stock) so that the movement of both tend to fluctuate together.

The occurrence of the same movement, making the alleged linkage between the two. With the volatility that occurs, there will likely be a contagious effect (spillover) occurs between changes in the market with other markets. In this study, the authors wanted to know the direction of movement of volatility spillovers occurring between the foreign exchange market as represented by the USD-IDR exchange rate and capital markets as represented by the Indonesian Stock Price on the period 2011-31 January 3 August 2016.

The foreign exchange market is a network that connects the centers of world foreign exchange trading, and a provider of institutional and physical structures. And the foreign exchange market is a means to trade or international trade and investment. (Sartono, 2012) In the foreign exchange market, there are two categories of currency is a currency that is not used (soft currency) and the currency used (hard currency) in international transactions. For soft currency is usually the currency of developing countries, while for hard currency is the currency of developed countries. (Kasmir, 2014)

The exchange rate is a product of the foreign exchange market, which is where the ratio of the exchange rate of a currency against other currencies. Or in other words, the exchange rate is the price of foreign currency expressed into domestic currency. (Keown et.al. 2010)

In the transaction, the exchange rate is divided into two types, namely the selling rate and buying rate. Selling rate is the price offered by the bank as the seller to the buyer. Buying rate is the price paid by the bank when buying from buyers. The exchange rate of a currency may vary due to several factors, including economic and political factors of the country or internationally. (Kasmir, 2014)

The stock market is concerned with the activities of the public offering and trading of securities, public companies relating to securities issuance, as well as institutions and professions related to the effect. (Act No. 8 th. 1995)

Stock exchanges are organizations / companies that organize or provide facilities to the market to bring together buying and selling securities deals between companies / individuals that are involved with the purpose of securities trading companies that have been listed on the Stock Exchange. (Darmadji et.al., 2011)

One is the effect of capital market products or better known as stock. Stock is one in which the stock of financial assets used as an individual form of a claim on the assets of their rill in companies. (Bodie et al, 2014)

Stock index can be regarded as the performance of the economy of a country. When economy situation of a country is strong, then the index of shares in the country will increase. And vice versa if the economy is experiencing a downturn, it can be estimated that the stock index at a stock exchange in the country is declining. Analysis of the economy can approach and analyze the macroeconomic conditions in the country. (Wira 2011)

Indonesian Stock Price is an index of shares owned by the Indonesian state by using all the company was recorded as a component of the index calculation. Introduced on April 1, 1983 as an indicator of the whole movement of stock prices in the Indonesian Stock Exchange (BEI). (BEI, 2010)

Calculation for Indonesia Stock Price is:

$$
\text { index }=\frac{\text { market value }}{\text { base value }} \times 100
$$


Information:

- The market value is the cumulative total listed shares multiplied by the market price

- The base value is the cumulative number of shares on the basis multiplied by the price on the basis

- The number 100 is a constant

In terms of investment either short or long-term, risk and return is relevant, where the rate of return high will be associated with the level of risk is high, and vice versa. Condition rate of return is low will be associated with the level of risk is low anyway. The relationship between risk and return is shown in the graph the expected relationship between risk and return. In the graph illustrated an expected return rate, followed by the level of risk that will be faced. Therefore, investors generally invest by looking promising returns notwithstanding the level of risk that will be acquired. (Reily, et.al., 2012)

Contagion Effect itself is contagious effects (spillover) or transmission. Transmission is derived from a condition experienced by a country and trigger other countries around through the same thing. In this theory states that a country cannot ignore this phenomenon of contagion effect. (Trihadmini, 2011)

Volatility is the standard deviation of return that is based on the variable return per unit of time is increasing. Another definition says volatility as fluctuations or shocks that occur on a security at a specified time. When volatility is used for risk management, the unit is the unit of time spent per day, thus the volatility in risk management is the standard deviation of return growing every day. In addition, the volatility mainly due to new information in the market. The information that causes a person improve their opinion about the value of the assets, resulting in a change in the value and yield volatility. (Hull, 2015)

Volatility spillover is a statement that says the connectivity between different markets. (Palakkod 2012) Another definition of volatility spillover is to use express condition where there is instability which provides transmission from one market to another. (Wiryono et.al., 2009)

Based on previous research, that in the foreign exchange market with the capital market there is volatility spillover (Mishra et al, 2007; Mozumder et al, 2015). But there are also stating that there is no volatility spillover between the two markets. (Trihadmini, 2011). Of these events, that can be said that the results of a study can be said to be inconsistent even if the same research topic, it is possible the results will be the same anyway. The results of the study depend on other factors, including the selection of the region, the sample period, the frequency of the data and methodology used. (Lestano 2010)

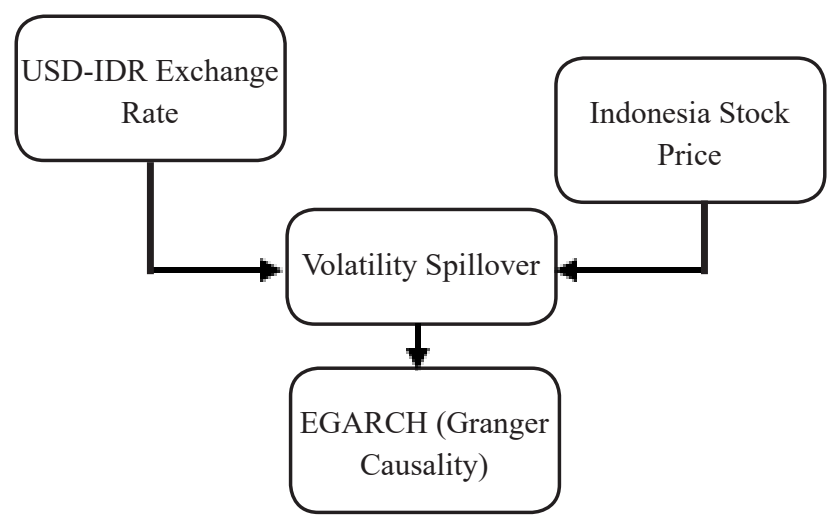

Figure 1. Framework Research

Information:

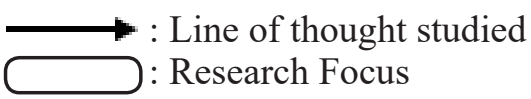

Based on the framework that has been described and research paradigm to figure 1, the proposed hypothesis:

There was a causal relationship between the volatility of the exchange rate of USD-IDR with Indonesian Stock Price

\section{METHOD}

The author takes a sample of the reference rate JISDOR (Jakarta Interbank Dollar Spot Rate) which presented the USD-IDR exchange rate USD-IDR in Indonesia. And the closing price Indonesian Stock Price presented the changes in value of Indonesian Stock Price. In this study, the authors used secondary data, where secondary data used is the data reference rate JISDOR USD-IDR daily obtained from the official website of Bank Indonesia, (www.bi.go.id) and data changes in the closing price Indonesian Stock Price obtained from the website of Indonesia Stock Exchange (www.idx.co.id).

Now to answer the problems in this study, the authors used time series data that will be analyzed by several methods, first test is Root Test Unit with Augmented Dickey-Fuller test, the development of recent testing to see the data had problems autocorrelation which is generally time series data is used, the data will undergo autocorrelation and the test was intended to see that the data is stationary and does not have autocorrelation. A second test of GARCH which is a test that serves to address the problem of heteroskedasticity commonly experienced time series data, and the third is test the Granger Causality Test, this is a test of data that is useful to know the direction of the variables studied had a two-way connection or only in one direction only. And all these analytical methods processed and calculated using statistical software. 
Researchers used a non-probability sampling with purposive sampling technique in performing the sampling for this research. Where a purposive sampling technique establishes that each element has an equal opportunity to be a sample of a study. Only the elements that meet certain criteria established writers can be sampled from the study. Where researchers perform sampling by specifying criteria for samples to be taken. The criteria of the samples taken are presented data that the volatility experienced by the exchange rate and stock index, after it determines the range of data collection to be studied. Researchers took a period of 5 years from 2011 - 2016. And the researchers extracted from the data that was published by Bank Indonesia and the Indonesia Stock Exchange on its website respectively.

Before entering the processing using software, the researchers first change the data reference rate JISDOR USD-IDR into the middle of a data value exchange rate USD-IDR by calculation using the following formula:

$$
\text { middle rate }=\frac{\text { selling rate }+ \text { buying rate }}{2}
$$

And then, after the midpoint of the exchange rate USD-IDR obtained, the authors conducted a median value of data conversion rate of USD-IDR and the closing price of the stock index into the data return $(\mathrm{Rt})$ that which is calculated by the same formula as follows:

$$
\mathrm{R}_{\mathrm{t}}=\frac{\left(\mathrm{P}_{\mathrm{t}}-\mathrm{P}_{\mathrm{t}-1}\right)}{\mathrm{P}_{\mathrm{t}-1}}
$$

Once the data has become a daily return data, step analytical methods used can be resumed. And here is the method of analysis used in this study:

Augmented Dickey-Fuller (ADF) Test. This test assumes that the data are not correlated. While time series data, that data is often experienced problems autocorrelation. If the data having problems autocorrelation in general the data is not stationary. As for analyzing time series data, the data must be a stationary data. Therefore, it is necessary for their further processing which developed the Dickey-Fuller Unit Root Tests with their test type called Augmented Dickey-Fuller (ADF) test. (Nachrowi et.al. 2006). The formula is as follows:

$$
\Delta \mathrm{Y}_{\mathrm{t}}=\beta_{1}+\beta_{2 \mathrm{t}}+\delta \mathrm{Y}_{\mathrm{t}-1}+\alpha_{1} \Delta \mathrm{Y}_{\mathrm{t}-1}+\alpha_{2} \Delta \mathrm{Y}_{\mathrm{t}-2}+\ldots+\alpha_{\mathrm{m}} \mathrm{m}+\varepsilon_{\mathrm{t}}
$$

Where:

$\mathrm{m}=$ length lag used

$\mathrm{Y}=$ the observed variables

$\mathrm{t}=$ time trend

By hypothesis:

H0: $p$-value $\geq \alpha$, then there is a unit root, the data time series is not stationary.

$\mathrm{H} 1$ : $\mathrm{p}$-value $<\alpha$, then there is no unit root, stationary time series data.
GARCH, this method is one method used to test the time series data. Where in general is often a problem occurs heteroskedasticity, for it is the use of methods GARCH helps authors in processing in this study where the data rate of USD-IDR daily and the closing price of INDONESIAN STOCK PRICE shows the volatility that occurs quite significant, which would certainly have a variant that is not constant, and experienced heteroscedasticity. GARCH model has become a common model that is often used in financial research to study the volatility. (Nachrowi et.al. 2006) GARCH represented by the following form:

$$
\sigma_{\mathrm{t}}^{2}=\alpha_{0}+\alpha_{1} \mathrm{e}_{\mathrm{t}-1}^{2}+\ldots+\alpha_{\mathrm{p}} \mathrm{e}_{\mathrm{t}-\mathrm{p}}^{2}+\lambda_{1} \sigma_{\mathrm{t}-1}^{2}+\ldots+\lambda_{\mathrm{q}} \sigma_{\mathrm{t}-\mathrm{q}}^{2}
$$

Where:

et-p $\quad=\mathrm{x}$ is a variable of the last period.

From the above model of a var (e) depending on the variant occurring in the past, which affects the long period can be limited in GARCH.

Granger Causality Test, granger causality test has the purpose of identifying a variable has a twoway connection or only in one direction only with other variables. (Nachrowi et.al. 2006) granger causality test conducted with the use of the following hypotheses:

\section{(A)H0 = USD-IDR exchange rate does not affect (not cause) Indonesian Stock Price \\ H1 = Exchange rate USD-IDR affect (cause) Indonesian Stock Price}

(B)H0 = Indonesian Stock Price does not affect (not cause) exchange rate USD-IDR

$\mathrm{H} 1$ = Indonesian Stock Price affect (cause) exchange rate USD-IDR

\section{RESULT}

Here are the results of tests performed with the help of software. Where the results of this test begin by looking at the results of the processing of descriptive statistics.

Table 1. Descriptive Statistic

\begin{tabular}{ccc}
\hline & $\begin{array}{c}\text { Exchange Rate } \\
\text { Return }\end{array}$ & $\begin{array}{c}\text { Indonesia Stock } \\
\text { Price Return }\end{array}$ \\
\hline Mean & 0.000284 & 0.000313 \\
Median & 0.000109 & 0.000563 \\
Maximum & 0.063914 & 0.047586 \\
Minimum & -0.065114 & -0.088804 \\
Std. Deviation & 0.005258 & 0.010940 \\
Skewness & -0.285490 & -0.684697 \\
Kurtosis & 36.69385 & 8.937866 \\
\hline Observation & \multicolumn{2}{c}{1455} \\
\hline
\end{tabular}


For further testing to see the data is stationary or not, because in general the time series data stationary frequently encountered problems where the data is not stationary. To make the data be stationary then made changes to the data of the time series into the data return every day.

Table 2. Result of Unit Root Test with Augmented Dickey-Fuller

\begin{tabular}{lcc}
\hline $\begin{array}{c}\text { Augmented Dickey-Fuller } \\
\text { test statistic p-value }\end{array}$ & Level & First Difference \\
\hline Exchange Rate USD-IDR & 0.8725 & 0.0000 \\
Indonesia Stock Price & 0.4408 & 0.0000 \\
\hline
\end{tabular}

Continue to testing heteroskedasticity useful to look at the diversity of the data processed.

Table 3. Result of Heteroskedasticity Test with ARCH Heteroskedasticity Test: ARCH

\begin{tabular}{llll}
\hline F-statistic & 19.36040 & Prob. F(1,1452) & 0.0000 \\
Obs*R-squared & 19.13197 & Prob. Chi-Square(1) & 0.0000 \\
\hline
\end{tabular}

Here are the results of the testing of data modeling with models EGARCH which is the latest model of the method ARCH.

Table 4. EGARCH Model

\begin{tabular}{ccc}
\hline Variable & Coefficient & Probability \\
\hline $\mathrm{C}$ & 0.000428 & 0.0642 \\
$\begin{array}{c}\text { Exchange Rate } \\
\text { Return }\end{array}$ & -0.391733 & 0.0000 \\
\hline \multicolumn{3}{c}{ Variable Equation } \\
\hline $\mathrm{C}(3)$ & -0.406665 & 0.0000 \\
$\mathrm{C}(4)$ & 0.159945 & 0.0000 \\
$\mathrm{C}(5)$ & -0.089552 & 0.0000 \\
$\mathrm{C}(6)$ & 0.969288 & 0.0000 \\
\hline
\end{tabular}

And at the end of the test in this study conducted testing to see the direction of the market, there was a two-way causal relationship or only in one direction only. The test is called the Granger Causality Test.

Table 5. Result of Granger Causality Test

\begin{tabular}{cccc}
\hline Null Hypothesis & Obs & F-Statistic & Probability \\
\hline Exchange Rate does not & & 4.44807 & 0.0119 \\
Granger Cause Indonesia & & & \\
Stock Price & & & \\
\cline { 1 - 1 } $\begin{array}{c}\text { Indonesia Stock Price does } \\
\text { not Granger Cause Exchange } \\
\text { Rate }\end{array}$ & 6.42375 & 0.0017 \\
& & & \\
\hline
\end{tabular}

\section{DISCUSSION}

This study uses time series data, which generally run into problems not stationary and happen heteroskedasticity. Of course, the data is not stationary cannot continue processing and analysis, for the time series data are first converted into data daily return that which gives the results of a brief overview which can be seen in Table 1 is a table of descriptive statistics daily return of the data used in the study this.

After the result of the value of daily return both the data, processing continues to the unit root test with Augmented Dickey-Fuller (ADF) to test the stationary of the time series data to obtain data that is stationary with the variance is not too large, and tend to approach the average value. Table 2 provides an overview of the results of data processing with Unit Root Tests performed on the data rate of USD-IDR and Indonesian Stock Price at the level and first difference.

By looking at the significance level $(\alpha)$ used is $5 \%$, the data of the exchange rate USD-S and Indonesian Stock Price are not stationary at the level for the value of $p$-values $\geq \alpha$. Level itself is the most basic level the unit root test to see whether a stationary data. The data still needs to be stationary, by changing daily data into data return and perform the unit root test on the first level of differentiation method (first difference). The results of testing on the first difference shows the p-values $<\alpha$ which means that return data exchange and return Indonesia Stock Price has stationary.

The results of the test root which has shown data is stationary, then proceed with the testing heteroskedasticity with ARCH. The following description of the test results ARCH heteroskedasticity method that can be seen in Table 3 .

The results of the test heteroskedasticity with $\mathrm{ARCH}$ shows that the value of the p-value Obs*R-Squared $=0.0000<\alpha$, in which $\alpha$ is $5 \%(0.05)$. This viewed heteroscedasticity test results that showed the presence of heteroscedasticity in the data, it can be continue to modeling with EGARCH because this model is the latest model of ARCH methods and do not consider heteroskedasticity as a problem, but can help remedy create forecasting models. The test results are shown in Table 4.

Modeling EGARCH in Table 3.4 shows the probability value of Exchange Rate Return $=0.0000$ $<\alpha(0.05)$, which means that there is volatility spillover between the foreign exchange market (USD-IDR exchange rate) and capital markets (Indonesian Stock Price). The results of this analysis EGARCH models still need to pass through several other tests including ARCH-LM test, normality test, and test serial correlation. The test is to prove that the results of the modeling EGARCH there are no ARCH effect, the data were not normally distributed and experienced no autocorrelation. After passing three tests, followed by granger causality test to determine the direction in which the movement of a spillover of volatility.

In this study, granger causality test was conducted to determine the USD-IDR exchange rate and Indonesian Stock Price have a relationship unidirectional, 
bidirectional, or do not have their relationship. With 1455 days of data observations, and Table 5 shows the results of testing granger causality of the data return rate of USD-IDR and return Indonesian Stock Price. Based on Table 5 shows that the results of granger causality test that has been carried out, which can be seen from the value shown that the probability that the relationship is a two-way relationship between Exchange Rate against Indonesia Stock Price and Indonesia Stock Price against Exchange Rate. That which means that if there is a change in the exchange rate of the composite index would be affected and vice versa, in the event of any changes in Indonesian Stock Price then the exchange rate will be affected.

By looking at the results of this study illustrate that there is a correlation between the two markets. Where the real conditions at this time that the foreign exchange market and the shares have the same movement can be said to be mutually affect where the current foreign exchange market occurred rupiah weakened the dollar exchange rate at that time the value of the stock will decline because of factors investors in the stock the effect that most foreign investors sell shares they own in order to minimize losses resulting from the value of the rupiah slumped.

\section{CONCLUSION}

In the period of research conducted with data from the date of January 3, 2011 until August 31, 2016, with a data rate of USD-S and Indonesian Stock Price are stationary at first difference and data experience volatility spillover between the foreign exchange market and the capital market with EGARCH method. And testing granger causality shows that the direction of a spillover of volatility in both markets is a two-way relationship, in which case changes in the foreign exchange market, the capital market has undergone a change and vice versa where if there is a change in the capital markets, the foreign exchange market has undergone a change as well.

This study has limited information where the results of this study only provides information that the economic actors, especially the investors should be more cautious in investing in the stock market, which is where the results of this study, the investor can find out that the condition of the market of foreign exchange also affects conditions on the stock exchange where the investors to invest.

\section{REFERENCES}

Arini, Nisa Nur, Rikumahu, Brady. Iradianty, Aldilla. 2016. Volatility Spillover Between USD-IDR Exchange Rate Changes And Indonesia Stock Index - APIAR. Vol.2 Hlm. 320-327
BEI. 2010. Buku Panduan Indeks Harga Saham Bursa Efek Indonesia. Jakarta: Bursa Efek Indonesia.

Bodie et al. 2014. Manajemen Portofolio dan Investasi, Edisi Kesembilan, Jilid 1. Jakarta: Salemba Empat

Darmadji, Tjiptono dan Fakhruddin, Hendy M., 2011. Pasar Modal di Indonesia, Edisi 3. Jakarta: Salemba Empat

Hull, Jhon. C. 2015. Risk Management and Financial Institution: Forth Edtion. Willey Finance Series.

Kasmir. 2014. Bank dan Lembaga Keuangan Lainnya. Jakarta: Rajawali Pers.

Kementerian PPN/Bappenas. 2013. Perkembangan Ekonomi Indonesia, Triwulan II Tahun 2013. Jakarta: Deputi Bidang Ekonomi.

Keown et.al. 2010. Manajemen Keuangan: Prinsip dan Penerapan, Edisi Kesepuluh, Jilid 2. Edisi Bahasa Indonesia: PT INDEKS

Laporan Tahunan KSEI. 2015. Expansion \& Integration for Invesment Convenience. Jakarta: PT. Kustodian Sentral Efek Indonesia.

Lestano, Sucito Julio. 2010. Spillover Volatilitas Pasar Saham Indonesia dan Singapura Periode 20012005. Jurnal Akuntansi Dan Keuangan, VOL. 12. 17-25.

Mishra, Alok Kumar., Swain, Niranjan., Malhotra, D.K. 2007. Volatility Spillover between Stock and Foreign Exchange Markets: Indian Evidence International Journal of Business. Vol. 12 No.3. Hlm. 343-359

Mozumder, Nurul., Vita, Glauco De., Kyaw, Khine S., and Larkin, Charles. 2015. Volatility Spillover Between Stock Prices and Exchange Rates: New Evidenve Across the Recent Financial Crisis Period. Economic Issues, Vol. 20. Part 1. 43-64

Nachrowi, Nachrowi dan Usman, Hardius. 2006. Pendekatan Populer dan Praktis EKONOMETRIKA untuk Analisis Ekonomi dan Keuangan. Jakarta: Lembaga Penerbit Fakultas Ekonomi Universitas Indonesia.

Palakkod, Suhail. 2012. Integration of Capital, Commodity, and Currency Markets: A Study on Volatilty Spillover - The Romanian Economic Journal. Year XV. No.44. Hlm. 87-98

Reily, Frank K. dan Keith C. Brown. 2012. Investment Analysis \& Portofolio Management (10th Edition). USA: South-Western Cengage Learning

Sartono, Agus.2012. Manajemen Keuangan Internasional. Yogyakarta: BPFE.

Trihadmini Nuning. 2011. Contagion Dan Spillover Effect Pasar Keuangan Global Sebagai Early Warning System. Finance and Banking Journal, Vol. 13 No. 1 Juni. 47-61

Undang-undang Pasar Modal No. 8 Tahun 1995 tentang Pasar Modal 
User. 2013. Perkembangan Internasional 2013: III. [online] http://macroeconomicdashboard.feb. ugm.ac.id/perkembangan-internasional-2013-iii/ [sumber data: Badan Pusat Statistik dan CEIC 2013] [akses September 07,2016 10.00]

Wira, Desmond. (2011). Analisis Fundamental Saham.
Jakarta: Exceed.

Wiryono, Sudarso Kaderi dan Widjonarko, Yohanes Edward. 2009. Volatility Spillover between Stock Market and Foreign Exchange Market in Indonesia -School of Business and Management Institut Teknologi Bandung. Vol. 8 No.2. 